\title{
Technical Issues in E-Governance Initiatives in Satara District in Maharashtra State (India)
}

\author{
Laxman L. Kumarwad \\ Government College of Engineering, Karad, 415124, India \\ Email: laxmankumarwad@gmail.com \\ Rajendra D. Kumbhar \\ KBP Institute of Management Studies and Research, Satara, 415015, India \\ Email: rdk14@rediffmail.com
}

Received: 10 June 2017; Accepted: 13 July 2017; Published: 08 January 2018

\begin{abstract}
Maharashtra is one of the biggest states in India. The state as well as the central government is spending millions of rupees for providing the online services. However, their efforts and large investments result into launching various e-governance projects in the country. Common Service Centre, Public Distribution System and Land Record System, three projects are very important as citizen's centric services concern. These projects are implemented by the state government through their subsidiary offices. Collector office is one of them. At the district level, Collector office is responsible for implementing and smoothly running of the egovernance projects. A rapid change in the technology is forcing new changes to be accepted in the e-governance domain. Considering these changes, government is slow in redefining the Government Process Reengineering, citizens' relation, employee relationship. There are a lot of issues arise at the ground level in the implementation of the projects. Issues can be categorized as technical, administrative, financial, managerial etc. This research paper focuses on technical development and technical issues found in Satara district at the ground level while developing, implementing, delivering the services to the citizens, business and government and sustaining the projects.
\end{abstract}

Index Terms - CSC, SDC, SWAN, MahaGov Cloud, eGLC, Agile Methodology

\section{INTRODUCTION}

Electronic Governance is the service delivery to the citizens, business and government from the government through the information and communication technology (ICT). The electronic government essentially refers to the emphasis on utilization of ICT for delivering public services to citizen's doorstep, businesses, and government itself. The most prominent advantage of egovernment from an organizational point of view is to improve the efficiency and effectiveness of the existing system so that, it results into saving public money, efforts and time. While delivering the services to the various stakeholders of the society, it is the duty of government to design integrated services and the citizen centric system and deliver services at the doorstep of the citizens, seven days of a week and twenty-four hours. Among these services, some services initiated and maintained by the central government, some services by the state government and some by local bodies. Common Service Centre (CSC), Public Distribution System (PDS) and Land Records System (LRS) are most important in the district level administration.

From the citizens' point of view, one of the most significant benefits of electronic government over a manual system is 'anywhere and anytime' availability of government services to the citizens. Apart from this, there is a provision of local or multilingual information content, user friendly navigation, accessibility of information, regular updates and latest changes in government services and schemes. Recently, Maharashtra state has made significant progress in the area of ICT in the form of Digital India, MyGov (Aaple Sarkar) [1]. In the last few years, Maharashtra government has also realized that ICT has played a crucial role in transforming government services to the doorsteps of the citizens. In this research paper, we are taken technical aspects into consideration right from the procurement of the e-governance project up to the implementation and sustainability of the project in the Satara district.

\section{RELATED WORK}

There has been some prior works done in the egovernance literature. Ch. Radha Kumari (2003) in her article [2] discussed about the impact of e-Seva in Andhra Pradesh. Her study reveals that the citizens are willing to pay the nominal extra charges for improved and cumbersome-free services. The working hours and days of the service centres are providing convenience and benefit, particularly to working or employed citizens. Bhudeb Chakravarti et al. (2008) published a white paper [3] stated that the bureaucratic approach cannot provide the expected outcomes from the computerizing the 
government offices or departments. Sam Felix et al. (2011), in this article [4] the researchers concluded that egovernance projects are strategic to the economic and social development of any society. E-Governance project implementations usually span a long time and touch a large spread of stakeholders. The success or failure of such projects largely depends on the coordination and cooperation between various stakeholders, effective management and optimal use of technology. Sushil Kumar Singla et al. (2011), in his research paper [5] author specifies the great scope of improvement in service delivery system and time taken for delivery of service; Government should provide better facilities and training to staff. So, improvements could facilitate citizens to get hassle free service delivery at their door step. Balakumaran P J and et al. (2013) in their research paper [6] studied the reasons behind poor performance of local self governance system and proposed interactive egovernance system solution combining with data mining which overcomes the technical problems. In their research .NET 3.0 Framework used to developed egovernance system called 'Panchayat System'.

\section{SATARA DiSTRICT ADMINISTRATION}

Satara district is located in Sahyadri range of the Western Ghats under the Pune Administrative division in the Maharashtra state in India. Geographical location of the district is on north latitude $17.5^{\circ}$ to $18.11^{\circ}$ and east longitude $73.33^{\circ}$ to $74.54^{\circ}$ [7]. District spread across $10475 \mathrm{~km}^{2}$ area surrounded by Pune district to the north, Raigad district to the north-east, Ratnagiri district to the west, Sangli district to the south and Solapur district to the east. The population of the district is 3003741 of which $14.17 \%$ were urban and the literacy rate is $82.87 \%$ [8]. The Satara district has 4 sub-divisions namely Satara, Phaltan, Karad, Wai and 11 talukas namely Satara, Karad, Koregaon, Khatav, Patan, Phaltan, Man, Wai, Khandala, Mahabaleshwar and Jaoli. There are 8 assembly constituencies, 15 towns and 1739 villages [7]. Marathi is the official language and is written in Devanagari script [9]. All e-Governance projects is handled by the eDistrict Manager and reports to Deputy Collector.

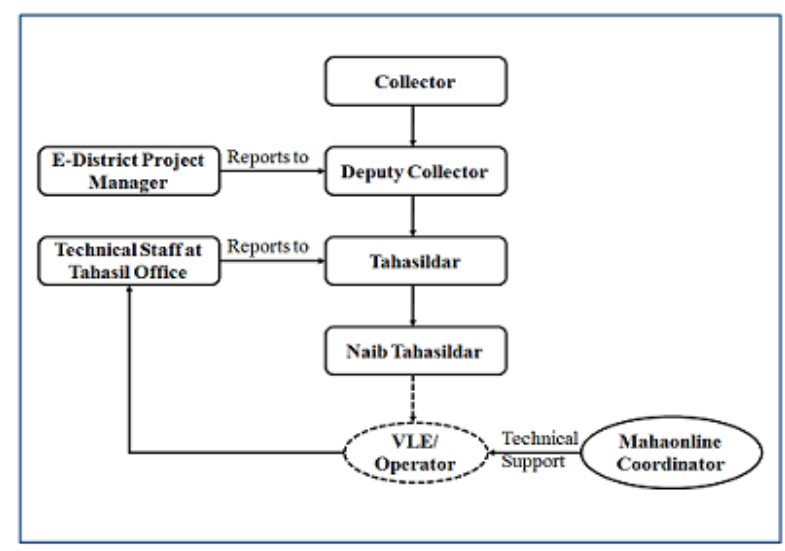

Fig.1. E-Governance Project Organizational Structure
Mahaonline Coordinator gives the technical support to the VLE/Operator and look out the Mahaonline related issues throughout the district. Technical staff associated with the respective Tahasil office and reports to Tahasildar of respective Taluka. Figure 1 shows the egovernance project organizational structure in Satara district.

\section{RESEARCH METHODOLOGY}

The study has used both primary as well as secondary data for research purpose. The primary data is collected through the interview and questionnaire from the stakeholders of the e-governance initiatives in Satara district. We have focused on the technical aspects, so the researchers chosen such stakeholders for the interview who directly associates with the e-governance project implementation and maintenance like Project Manager, Project Coordinator, Technical staff from the Collectorate Office, Tahasil Office. Village Level Entrepreneur (VLE) can be work as operator or employ the technical persons as the operator in the CSC. Researchers selected 109 CSCs of 151 CSCs through the proportionate stratified random sampling method from the 11 Talukas of the Satara district. The operator respondents were identified on the basis of their job level and working experience in selected CSC. Total sample size of operators selected is 109. The questionnaire is formulated with close-ended technical questions with multiple choices and responses are collected from the operators. We have used secondary data for analysis. Sources of the secondary data are from the Gazetteer published by the state and central government, census data published by the Census of India, various websites, technical papers published by various agencies, research papers published in journals and conferences proceedings and policy documents.

\section{TECHNICAL INFRASTRUCTURE IN E-GOVERNANCE}

The rapid changes in the ICT are pushing the government into information based society from the product based. In the e-government project, the main issue is technical sustainability which has a very little control and much locally developed software might be problematic in the sustainability of the project. The egovernance solution must be the long run and sustain in any conditions.

The government must use the cutting edge information technologies like Big Data, Cloud Computing and Mobile Computing. These technologies have the ability to develop a good relationship with the citizens, businesses and other departments of the government. These technologies can give the different variety of services like improved service delivery to the citizens, better interactions with industry and business and information access empowerment to the citizens. E-Governance is an enabler of good governance as it has the potential to reduce bureaucracy and power to facilitative citizen participation. Directorate of Information Technology 
(DIT) of Maharashtra is responsible for the implementation of e-governance projects in the state. Egovernance project implementation is a very complex process requiring provisioning software and hardware, networking, process reengineering, capacity building, change management [10]. In the past, it has been observed that most of the e-governance projects have been undertaken through individual initiatives; some of them have produced the desired results while some are not succeeded or withstood the test of time. Therefore, a prudent approach is suggested for the National eGovernance Plan (NeGP), which is based on lessons learnt from the past experience from successful implementation of e-governance projects within the country and internationally. The approach and methodology adopted for NeGP contain the following technological elements:

\section{A. A Common Support Infrastructure}

For the implementation of the e-governance project, need statewide common dedicated infrastructure. Maharashtra state has the following infrastructure.

1) State Wide Area Network (SWAN): State Wide Area Network in Maharashtra is called MSWAN. MSWAN composed of three-tier architecture i. e. State Headquarter, District Headquarter, Taluka Headquarter. MSWAN, a gateway to multi-nodal services provides vertical connectivity to facilitate the seamless integration of 366 offices from the state secretariat office to the district collectorate office to taluka level office. This network supports data, voice, video applications and unique departmental applications.

2) State Data Centre (SDC): Cloud platform avoids duplication of infrastructure and helps in interdepartmental coordination for service delivery [11]. Maharashtra government operates a fully functional Tier 2 Data Center as per TIA-942 standard located in the secretariat in Mumbai. This is the first SDC in India to have fully operational government cloud called MahaGov Cloud. SDC is dedicated to the service offers by the Maharashtra state. SDC is the repository of data which gives service by the state government. MH SDC offers services like cloud services, manage hosting and colocation services [12]. Figure 2 shows the Maharashtra state SDC structure.

3) Common Service Centre (CSC): The CSC project was implemented in September 2008 in Maharashtra. Since its inception not only providing Government to Citizen (G2C) and Government to Business (G2B) services to the citizens but also promoting the rural entrepreneurship among the villagers called as Village Level Entrepreneurs (VLE). CSC in Maharashtra is called Maha e-Seva Kendra or SETU and serves through Mahaonline (MOL) portal. Maha e-Seva Kendras are the interface between the government e-service and the citizens which also provides services to the business. CSC scheme of government aims to cover six villages in one CSC and one SETU in each Tahasil but in Satara district, there are total 357 CSCs out of which 151 active, including SETU. Maharashtra government and Tata Consultancy Services (TCS) are jointly providing more than 140 online services to the citizens through the Mahaonline portal [13].

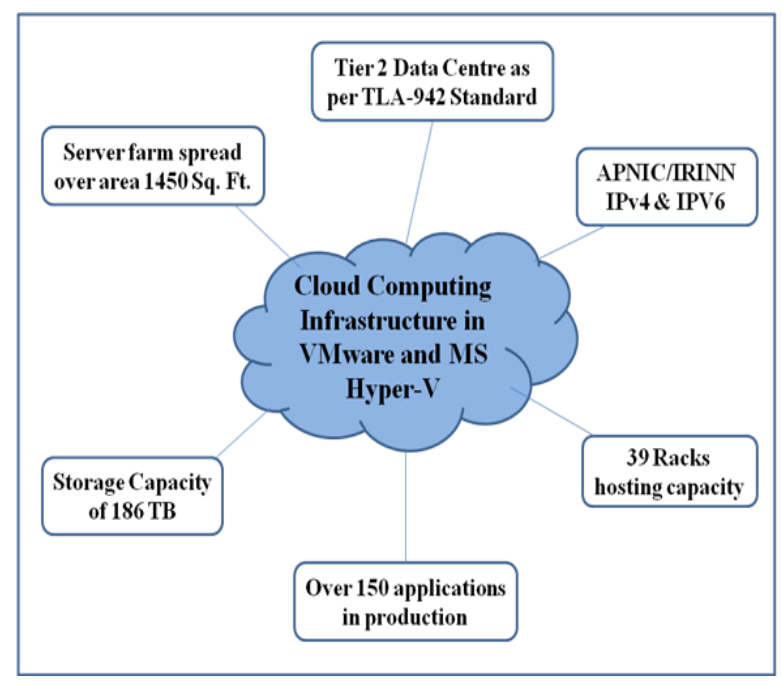

Fig.2. Maharashtra State SDC Structure.

MSWAN, SDC and CSC are the three pillars of the egovernance infrastructure. They provide efficient delivery of web-enabled anytime and anywhere access to information and services across the state. This infrastructure is used by the state government for their initiatives like Maha e-Seva Kendra, SETU, Land Record System, Public Distribution System and other initiatives. Table 1 shows the taluka wise population, total CSCs allotted, active SCSs and transactions count in the month of June 2016.

Table 1. Taluka wise CSC and Transactions in June 2016

\begin{tabular}{|c|c|c|c|c|}
\hline Taluka & Population & CSC & $\begin{array}{c}\text { Active } \\
\text { CSC }\end{array}$ & $\begin{array}{c}\text { Trans- } \\
\text { actions }\end{array}$ \\
\hline Satara & 502049 & 56 & 22 & 10397 \\
\hline Karad & 584085 & 67 & 28 & 10020 \\
\hline Koregaon & 257500 & 45 & 16 & 6948 \\
\hline Khatav & 275274 & 40 & 19 & 8741 \\
\hline Patan & 299509 & 38 & 18 & 14677 \\
\hline Phaltan & 342667 & 30 & 13 & 8151 \\
\hline Man & 225634 & 23 & 13 & 3763 \\
\hline Wai & 200269 & 21 & 10 & 4618 \\
\hline Khandala & 137418 & 20 & 8 & 2392 \\
\hline Maha'war & 72830 & 9 & 2 & 350 \\
\hline Jaoli & 106506 & 8 & 2 & 17 \\
\hline Total & $\mathbf{3 0 0 3 7 4 1}$ & $\mathbf{3 5 7}$ & $\mathbf{1 5 1}$ & $\mathbf{7 0 0 7 4}$ \\
\hline
\end{tabular}

\section{TeCHNICAL Issues E IN E-GovernANCE}

In this section covers the technical issues while implementation and sustaining the CSC, PDS and LRS e- 
governance initiatives in Satara district of Maharashtra state:

\section{A. Procurement of E-Governance Project}

Procurement of the e-governance project means procurement of the information system. Procurement of the information system poses many unique challenges in the government procurement process. Information systems are highly affected by changing technical and business objectives. They are subject to rapid technological changes over the project lifecycle. It is the mixture of professional engineering services and supply of diverse hardware and software technologies. In much procurement, technical contents are diverse and difficult to define. The procurement process is very slow due to the red-tapism process in India.

\section{B. Software and Hardware}

CSC operators are the end user of the e-governance applications through the Mahaonline portal. All CSC operators in the district use MS-Windows platform for accessing the portal through the browser. 87.16\% of operators use Windows 7 whereas $12.84 \%$ of CSC operators use Windows XP operating system. Egovernance portal gives the best performance on Mozilla Firefox (68.81\%), Google Chrome (28.44\%) and rest $(2.75 \%)$ other browsers. According to the CSC operators, $35.78 \%$ is software issues, $33.03 \%$ issues related to both software and hardware and $28.44 \%$ issues are related to other as shown in figure 3 .

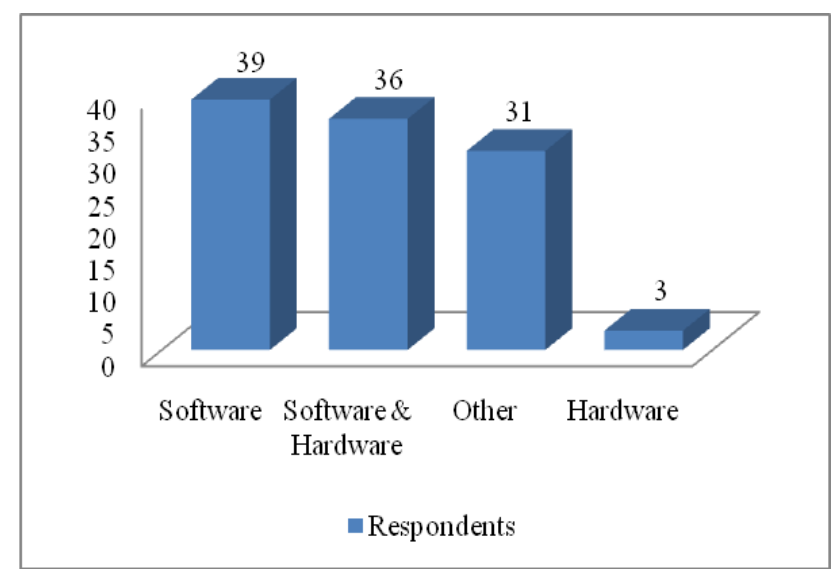

Fig.3. Software and hardware issues in e-Governance applications

\section{Technical Support}

The higher level technical team is responsible for troubleshooting the technical issues but $34.86 \%$ of operators replied that the higher technical team sometimes helps to troubleshoot the technical problem, $29.36 \%$ always help, $19.27 \%$ never help and $13.76 \%$ rarely help. Figure 4 showing technical issues while using the e-governance applications in Satara district.

\section{Connectivity}

CSCs are the main outlet for providing citizen's services. CSCs are facing the technical problems especially in the remote area where connectivity is slow. Almost all CSCs in Satara district, connected through the wired connection. $80.73 \%$ of CSCs have Internet connection from Bharat Sanchar Nigam Limited (BSNL). There is dependence on private operators for CSCs to get a connection in remote areas, as getting last mile connectivity from BSNL is a challenge in remote areas. $23.85 \% \mathrm{CSC}$ are having below $1 \mathrm{Mbps}, 38.53 \% \mathrm{CSC}$ are having $1 \mathrm{Mbps}, 32.11 \% \mathrm{CSC}$ are having $2 \mathrm{Mbps}$ and $5.50 \% \mathrm{CSC}$ are having $5 \mathrm{Mbps}$ Internet connection bandwidth.

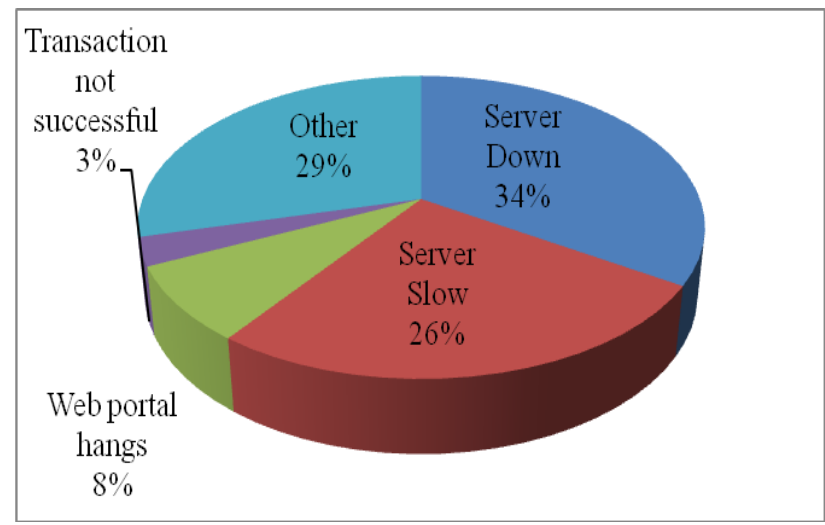

Fig.4. Technical issues while using the e-Governance applications.

\section{E. Technical Staff}

For implementation and sustaining of the e-governance projects, there is a need for technical manpower. Unfortunately, there is a shortage of technical manpower in most of the government departments. Employees who are near to their retirement do not want to learn or develop the technical skills. So the capacity building in government departments is very big challenge. In Satara district, one e-district project manager who maintains and manages all e-governance projects in the district, one MOL District Coordinator who takes care of Mahaonline portal related technical issues and each Tahasil Office is having only one technical person to maintain or solve the technical problems in Tahasil area. There is total 13 technical staff employed on contractual basis.

\section{F. Operators}

VLE can be work as operator or employ the technical persons as the operator in the CSC. Operators are the real users and key actors in the e-governance system because the operators directly interact with the e-governance applications. Operators are the interface between the egovernance system and the citizens. Operators are contractually recruited for look out the e-governance applications and to provide the services to the citizens in the district. In Satara district, $77 \%$ CSCs are operated by male, $52.29 \%$ operators' lies between age group 18 to 30 years and average age is 33 years. $51.38 \%$ operators are graduated and $24.77 \%$ operators are from arts background. Furthermore, $44.04 \%$ operators are passed Course on Computer Concepts (CCC) examination.

\section{G. Integration of Service}


There is a lack of interdepartmental coordination about data sharing in the government departments which lead to problems of integration of services among the departments. Considerably, it is high between the state government and local bodies. UID number can be used as a unique number for different service integration purpose. To overcome the integration of service issues, utilization of a technology which linkage of UID with the government service to the citizens [14].

\section{H. Interoperability}

Integration of data is a critical issue. To capture the data in the web-based form and to transfer it in the normalized form for sharing and processing the information is problematic. E-Governance architectures need to ensure that the components are backward and forward compatible with the system.

\section{Security and Privacy Issue}

As security and privacy issues concern, government and local body posts citizen's personal information like names, date of birth, and the contact number on their website without any password protection for the documents. This may cause to the misuse of private information. Due to this reason, citizens are not interested in availing the e-services. Government's primary duty is to protect the public data by implementing security majors in the e-governance project. The government takes care of the security and privacy of the data while designing and developing the e-governance projects. Security and privacy for information can be achieved by strengthening infrastructure, but these issues are often neglected. To avoid these issues, data should be stored in the encryption format, strong user authentication to identify the user, periodically e-governance projects should undergo for security audit by the third party security audit agencies/vendors.

\section{J. Authentication}

The citizen's as well as all VLE's authentication requests need to be verified before the use or access the service. These can be achieved by implementing eauthentication, e-verification, One Time Password (OTP) or 2 step verification. Software developed by Mahaonline for the issue of certificates is a good but variations in certificates format in different Tahasil. Some government officers are reluctant to accept these certificate formats for authentications generated by Mahaonline software. They accept those certificates which are in their format only. In this case, Mahaonline doesn't support to VLE. In this case, Mahaonline needs to be given support to VLE and insists Tahasil Officers to issue authenticated certificates in the standard format approved by DIT.

\section{K. Vendor Lock-In}

Vendor lock-in is the lack of compatibility between different software systems. Vendors or software solution communities may develop dissimilar versions of the same system architecture that cannot interoperate. They develop their software so that upgrades, add-ons and patch-ups must be purchased or take the service from the same company or vendor, rather than from a third party. This is called the Vendor Lock-in. Due to this, data available in one system cannot easily move to another system. So the problems of vendor lock-in results into the non-uniformity and non-availability in running legacy software, which is already in place [15]. To overcome these problems adopt OSS solutions.

\section{Language Compatibility Issues}

As per government resolution, local language i.e. Marathi is compulsory in Maharashtra for official work. Centre for Development of Advance Computing (CDAC) and Centre for India Language Technology, IIT Mumbai are the government organization which has been pursuing research in Indian language technology. The national standard IS13491:1991, Indian Standard Code for Information Interchange (ISCII) has not been fully compiled by a number of vendors to hold on their captured market segment [16]. In this research, it is found that $60 \%$ of VLE never faced language compatibility issues whereas $22 \%$ of VLE sometimes faced language compatibility issues.

\section{SUGGESTIONS}

Based on the study undertaken on e-governance initiatives in Satara district, there is a wide scope for effective and improving the e-governance services in terms of saving the cost, time and efforts. For the success of e-governance projects and citizen centric service delivery, government should focus on stakeholder's experience. Hence, the following suggestions are point out for long term sustaining of the e-governance projects and effective service delivery.

\section{A. Start Small, Think Big and Go Fast}

The government having limited resources i.e. in the form of technology and human capacity. Therefore, egovernance projects should be backward compatible with the existing ICT resources. Instead of directly implementing in the large scale process re-engineering and backend computerization, go with taking small steps is more probable to succeed. The government should initiate the projects by the simple provision of information on the web, and slowly work our way to achieve the long-term vision of an integrated platform for delivery of e-services.

\section{B. Avoid Traditional Models, Follow eGLC}

Traditional model starts with the requirement gathering and communicated to the software development team by the business analyst. Software development team translates these requirements into software. Once the development of software is completed, the client checks the product against the requirement specifications then acceptance testing is carried out. The software is deployed on the client side without much change in requirements from one phase to another phase. This model is more or less technology oriented but on another 
hand e-governance project is more management oriented. In the e-governance project development, an application runs the risk of failure so this method is not capable of catering to the change in requirements and the priority. Government departments involve in multiple functions and officers involve in handling multiple portfolios. In addition to these new schemes, tasks and projects are added. Actually, one office doesn't cooperate with another though within the same department. So the problems arise while requirement gathering from the stakeholders in the departments in a single cycle. Required information is not provided at the time of the initial phase. The software development team may become redundant by the time the concerned department is readied for user acceptance. This would cause initiation of next phase, development and testing, causing the interruption in the project implementation. By the time the next upgraded version of the project is presented, the government or departmental officials may have lost their interest or priority may have changed, especially when the boss changes. This may lead to an endless loop of requirement gathering and subsequent development, may result in failure of a project. Therefore, traditional models for e-governance project development likely to be time consuming. To avoid these issues use the E-Governance Project Life Cycle (eGLC) for the development of egovernance projects.

\section{Agile Methodologies for Project Development}

Instead of taking years to completely the automation of all the processes of the government departments or an activity using the conventional waterfall model, use agile methodology to succeed in project development. Applying agile development methodologies on egovernance project development increases the chances of project success.

\section{Government Process Reengineering (GPR)}

It is essential to redesign the processes in the government sector for achieving drastic changes in the performance of service delivery. Process redesigning includes the critical analysis and radical redesign of government processes and workflows between and among the government departments. Income certificate is required for educational purpose to the student, farmers require for apply for the crop loan. Citizens can apply for the income certificate at the CSC but the applicant should attach the attested photocopy of the ration card, voter card and aadhar card etc. The government already has these records with their subsidiary department; asking these records for issuing income certificate is redundant activity. Therefore, redefining the processes and removing the redundant processes is essential to revamped facilitate to the citizens. Procedures can be entirely revamped through the use of Information Technology. In the above case, attested photocopies of ration card, voter card and aadhar card documents are not required if access to these online records is granted to the concerned officials requiring this proof.

\section{E. Centralized Initiative and Decentralized Implementation}

In India, various projects decision is taken by the central government and implemented by the state government. When the decision is taken at the central level then why implementation should decentralize? This leads to confusion and contradiction among the state governments while working at the ground level through their subsidiary offices. This may be one of the reasons for the failure of the project.

\section{F. Public Private Partnership (PPP)}

The government should adopt PPP model for implementation and sustaining of the e-governance projects in the public sector. Various private companies are playing an important role in providing e-services to their private clients and government departments. By adopting PPP model, it is feasible to enlarge the resource pool without compromising on the security issues. The best example for PPP model is the Maharashtra government and TCS is jointly providing the online services to the Maharashtra citizens, business and government through Mahaonline portal.

\section{G. Government Ownership and Private Facilitation}

E-Governance projects require external support and facilitation; In fact, an e-Governance project may not be designed and developed without private players support. In this, DIT plays important role in coordinating and cooperating with the government and the private companies. The government should be promoting the involvement of the stakeholders of the society. Mahaonline portal is the perfect example of this concept. The government should adopt PPP model for implementation and sustain the e-governance projects in the public sector. Various private companies are playing an important role in providing e-services to their private clients and government departments. By adopting PPP model, it is feasible to enlarge the resource pool without compromising on the security issues.

\section{H. Low Cost Based Selection (LCBS)}

In Maharashtra state, e-governance much work has already been done. Wherever possible, no need to develop the module which is already developed the solution; integrate the solution with minor customization and save time, effort, and money. Use the ready-made Government eProcurement Solutions of NIC (GePNIC) solution developed by National Informatics Centre for the quick procurement process.

\section{Appointment of Regular Technical Staff}

Technical staff plays a very crucial role in implementation and sustaining of the e-governance projects. Recruitment of these positions should be regular with the essential technical qualification.

\section{J. Development of Mobile Apps}


Now days most of the services are available on mobile phones, tablets etc. This is the era of "e-services on the move". The government need to develop and start services on movable electronic gadgets also. Mobile applications are developed and integrated with the egovernance projects for giving the online services. Some of the services have already initiated and working on mobile apps like utility bill payments, service requests, mobile wallets etc. This concept is called m-governance which improves the efficiency and effectiveness of government service delivery.

\section{K. Connectivity}

Citizens able to use the online service when the internet connectivity available in their locality. The internet connectivity must available in every corner of the district. Government should provide the high speed internet connectivity at the low cost so as common people able to use the e-governance services on their smart phone or desktops.

\section{Use of Open Source Softwares (OSS)}

Government should promote the use of open source software and cutting edge technologies for the development of e-governance applications. OSS's advantages are freedom from vendor lock-in, proprietary software, quality of solution and ability to customize and fix.

\section{Use of Cutting Edge Technologies}

Now days cloud computing and big data are the ideal combination together provides a cost effective and scalable infrastructure for the government services. Cloud computing technology is a revolutionary concept and becomes a transformative change for citizens, business and government. Cloud Computing provides on demand and supply basis scalable services like Software as Service (SaaS), Platform as a Service (PaaS) and Infrastructure as a Service (IaaS). The government can hire the services if don't want to invest in the procurement of software, platforms and hardware. These services can be useful when highly demand of services from the citizens or business. This concept is very useful for cost saving on the procurement of software, platform and hardware.

As government online services growing constantly as well the number of transactions are also day by day increasing. There is the issue of volumes of transactions and data analysis. Big Data is a new technology used to get analytical reports from huge historical and unstructured data. Analytical reports can help the government to take more corrective, better business decisions and to frame the policy for the betterment of society. Big Data shows new direction toward data analytics for the government policy makers as well as citizens for getting the most relevant reports in real time from the vast amount of data.

\section{$N$. Integration of Services and Data}

Government should focus on the development of the national database. All the government services should integrate to each other so as they share the common database throughout the country. This national database can access by any state or central government for their government services.

\section{O. Security and Privacy of Government Data}

Security and privacy of government data is the biggest challenge to the government agencies. The publication of health records, election data, census data tax returns or even court transcripts have all proved problematic for individual privacy in different contexts. Government publishes the data on the web without any password protection. Government should provide the security and privacy of the data so as the citizens can access his own data with entering the essential credentials.

\section{CONCLUSION}

A state like Maharashtra is the pioneer in implementing and sustaining e-governance projects. In spite of poor connectivity, insufficient technical staff, Maharashtra bagged more than 100 prestigious egovernance awards in India. The government should move towards the citizen centric approach by applying agile methodology rather than traditional approach. In Satara district, due to lack of technical staff, it is very hard to maintain the e-governance project. The government should recruit and appoint permanent technical and managerial staff in the departments as well as in government offices. Higher technical staff must acquire new technology through the training and as master trainers, they train technical staff. Adequate IT infrastructure procurement, deployment and management are facilitated through the Head of Technology. Integration of Services is very important for data sharing among the departments and strengthening the sustainability of the e-governance project. Therefore, there is need of development of national database in India.

There is a somewhat same scenario in all other districts of Maharashtra state. Instead of viewing narrowly towards technical issues, to overcome these problems, removes the managerial issues in the e-governance project management and reform in government process reengineering. There is potential for Research and Development ( $R \& D$ ) in e-governance, the government should boost for $\mathrm{R} \& \mathrm{D}$ activities in the department.

\section{ACKNOWLEDGMENT}

Our sincere thanks to Mr. Pankaj Veer, E-District Project Manager and Mr. Amit Ghadage, Mahaonline District Coordinator from Collectorate Office, Satara for giving valuable information and time. 


\section{REFERENCES}

[1] Government of Maharashtra, Aaple Sarkar: 2016. https://aaplesarkar.maharashtra.gov.in/en/. Accessed: 2016-01-18.

[2] Ch. Radha Kumari (2003), "Impact of e-Seva in Andhra Pradesh: A Study", Sri SatyaSai Institute of Higher Learning, Proceedings of international Conference on egovernance in 19- 21 December 2003, Department of Management Studies, IIT, Delhi, pp. 420-427. 2007.

[3] Bhudeb Chakravarti, M. Venugopal (May 2008) Published a White Paper "Citizen Centric Service Delivery through e-Governance Portal-Present Scenario in India" National Institute of Smart Government, Hyderabad, India, May 2008.

[4] Sam Felix, Pradeep Kumar and N Vijaykumar (2011), "Business Innovation through Technology- eGovernance", SETLabs Briefings Vol 9 NO 2 2011, 15-22.

[5] Sushil Kumar Singla, Himanshu Aggarwal (2011), Citizen's Satisfaction with SUWIDHA initiatives in the State of Punjab (India), International Journal of Computer Applications (0975 - 8887) Vol 31, No.8, 2011, 21-24.

[6] Balakumaran P.J and V. Ramamoorthy. H, "Evolving An E-Governance System for Local Self-Government Institutions for Transparency and Accountability", International Journal of Information Engineering and Electronic Business, vol. 5, no. 6, pp. 40-46, 2013.

[7] The Official Web Site of District Satara: 2016. http://satara.gov.in/. Accessed: 2016-05-12.

[8] Census of India Website: Office of the Registrar General \& Census Commissioner, India: 2016. http://www.censusindia.gov.in. Accessed: 2016-07-08.

[9] The Government of Maharashtra, 2006. Satara District Gazetteer. Directorate of Government Printing, Stationary and Publication, Maharashtra State.

[10] Second Administrative Reforms Commission, 2008. Eleventh Report on Promoting E-Governance-The SMART Way Forward. Government of India.

[11] L. Kumarwad and R. Kumbhar, "E-Governance Initiatives in Maharashtra (India): Problems and Challenges", Mecs-press.org, 2017. [Online]. Available: http://www.mecs-press.org/ijieeb/ijieeb-v8-n5/v8n53.html. DOI: 10.5815/ijieeb.2016.05.03. Accessed: 06-042017.

[12] Directorate of Information Technology, State of $e$ Governance in Maharashtra 2014. The Government of Maharashtra, Mantralaya, Mumbai.

[13] MahaOnline Limited, Maharashtra: 2016. https://mahaonline.gov.in. Accessed: 2016- 08- 07.
[14] L. Kumarwad and R. Kumbhar, 2017. [Online]. Available: http://www.iarjset.com/upload/2017/si/NCIARCSE2017/IARJSET-NCIARCSE\%2047.pdf. [Accessed: 06Apr-2017]. DOI: 10.17148/IARJSET/NCIARCSE.2017.47

[15] Challenges of Multilingualism and Possible Approach for Standardization of e-Governance Solutions in India: http://www.iceg.net/2007/books/2/5_301_2.pdf. Accessed:2016-08-10

[16] Technology Development for Indian Languages, "Indian Script Code for Information Interchange". ISCII: 2016. http://tdil.mit.gov.in/standards/iscii.aspx. Accessed: 201609-08.

\section{Authors' Profiles}

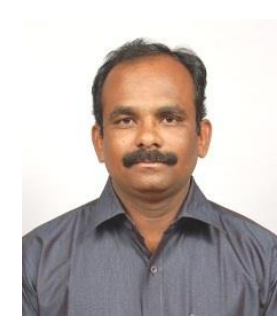

Laxman L. Kumarwad, Assistant Professor in Master of Computer Application Department at Government College of Engineering, Karad, Maharashtra in India. $\mathrm{He}$ is pursued MCA degree from University of Pune, India and now pursuing Ph.D. in Computer Applications from Shivaji University, Kolhapur, India. He has 8 years of teaching experience at Post Graduate level. His research activities include e-Governance, ICT.

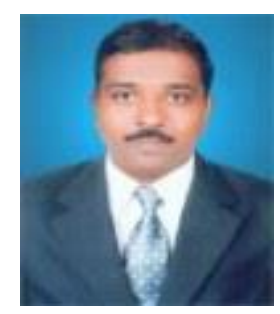

Dr. Rajendra D. Kumbhar, Assistant Professor in System Management Department of Karmaveer Bhaurao Patil Institute of Management Studies and Research, Satara, Maharashtra, India. He is pursued MCA, Ph.D. in Computer Applications from Shivaji University, Kolhapur. He has 16 years of Teaching experience in System Management for UG and PG programmes. His research area is e-Governance, ERP. He has published 26 research articles in refereed journal.

How to cite this paper: Laxman L. Kumarwad, Rajendra D. Kumbhar," Technical Issues in E-Governance Initiatives in Satara District in Maharashtra State (India)", International Journal of Information Engineering and Electronic Business(IJIEEB), Vol.10, No.1, pp. 1-8, 2018. DOI: 10.5815/ijieeb.2018.01.01 